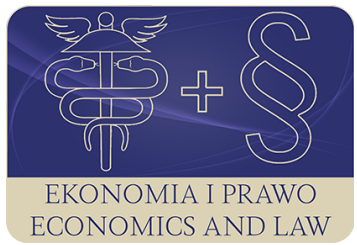

EKONOMIA I PRAWO. ECONOMICS AND LAW

Volume 18, Issue 2, June 2019

p-ISSN 1898-2255, e-ISSN 2392-1625

www.economicsandlaw.pl

EKONOMIA I PRAWO
ECONOMICS AND LAW

ORIGINAL ARTICLE

received 17.05.2018; revised 16.04.2019; accepted 30.06.2019

Citation: Olczyk, G. (2019). Elements of economic culture as informal institutions in the economic development of Germany. Ekonomia i Prawo. Economics and Law, 18(2): 233-244.

doi:10.12775/EiP.2019.017.

\title{
Elements of economic culture as informal institutions in the economic development of Germany
}

\author{
GRZEGORZ OLCZYK \\ Kozminski University, ul. Jagiellońska 57/59, 03-301 Warszawa, Poland \\ $\square$ golczyk@kozminski.edu.pl \\ (D) orcid.org/0000-0003-1305-430X
}

\begin{abstract}
Motivation: The author is interested in the problem of the economic development of a state wherein economic capital is described as a set of elements creating economic culture and informal institutions.

Aim: Identification of the operational conditions and manifestations of institutional economics in Germany may obtain an accurate picture and understanding of the functioning their counterparts in Poland. Article is also a proposal for the development of research in the field of institutional economics and economic culture.

Results: Putting the thesis that the German economy belongs to the group of the strongest in the world, the study revealed a pattern of results where the institutions were proposed as part of institutional economics, which determine economic development.
\end{abstract}

Keywords: economic and informal institutions; development; qualitative research JEL: D02; O17; O43

\section{Introduction}

Social institutions are the dominant ways of thinking in the right environment and functions of the individual and the community. The way the institution operates is characterized by the attitudes or concepts of life prevailing at a given time. The genesis of attitudes is found in the type of personality that dominates at a given time. Institutions are the habits of thought and the ways of capturing 
phenomena that guide human life. They come from and are a figment of the past adapted to the conditions of the time, which is why they are never in complete accord with the requirements of the present (Veblen, 1971, p. 171). In contrast, institutions, in terms of new institutionalism, are a concept that is a collection of various perspectives and disciplines in social sciences. In a universal approach, institutions are the context of social actors. This study adopts the category of historical and comparative institutionalism (Pawlak \& Srokowski, 2014, p. 10) and economic - of institutional economics (Federowicz, 2004, p. 65; Stankiewicz, 2012, p. 7), because economic institutions are customary ways of regulating the life processes of society in relation to the material environment in which the society lives (Veblen, 1971, p. 172), and institutions and culture are the foundations of each economic system (Ostrom, 2005; Phelps, 2013). That is why the power guiding the modern economics in the last two centuries is the economic system built on the economic culture, as well as economic institutions. Some, non-material motives and stimulants are important - possible even critical - for the functioning of the economy and in order to function, the modern economy must be fed with economic culture, as well as material stimuli (Phelps, 2013, p. 33).

\section{Literature review}

Contemporary literature divides institutional arrangements into four categories: institutional systems characterized by strong formal and informal institutions, solutions characterized by weak formal and strong informal institutions, system characterized by strong formal and weak informal institutions and institutional systems with a weak formal and informal impact. Correlations established between the four institutional categories and the gross domestic product of countries with such characteristics show that those belonging to the first two categories outperform, in terms of GDP per capita, countries from the otter two categories (Bostan et.al., 2016, p. 54; Williamson, 2009, pp. 371-387). Considerations of GDP are also the result of the studies by Ortowski (2015), who has supported the quantitative studies and the perspective of neoclassical economics, placing it in the context of Germany development, by discussions with the world of science - they are an additional empirical material of this study. The institutional approach, which is the equivalent of these reflections, and the development of the term 'dependence on the route' in the context of economic development, may be a proposal for further studies comparing the economic culture of Germany and Poland.

In this study, the cross-cultural issue, i.e. how Germany fits into various cultural dimensions (Gesteland, Hofstede, Hall and others), is one of three crucial issues in research in the context of economic culture (Kochanowicz \& Marody, 2007, p. 28; Porter, 2003, p. 59). Another one is the presentation of the concept of associations on the example of Stamtisch and cooperative as the genesis of the formation of institutions shaping the German social capital. The third el- 
ement of consideration is the so-called non-market knowledge transfer in German family businesses together with the elements of the apprentice system in the context of small and medium enterprises - as informal institutions. On the basis of the above wording, a thesis was formulated that says that elements of the economic culture, such as: creating unions, cooperatives and associations, transfer of knowledge within family enterprises, and dimensions of German culture with regard to communication in business are informal institutions within the institutional economy that decide about economic development.

\section{Methods}

According to the prerogatives in qualitative research, the exploration of the context of German economic culture is based on interviews conducted among research workers specializing in social sciences, economics, management, business ethics and intercultural communication, as well as business managers and practitioners at all levels of management in companies with German majority capital. The number of interviews depended on the degree to which the theory would be saturated. This is in the line with requirements of the well-grounded methodology theory, in which empirical data is classified, coded and finally are used for generating theories. For coding purposes, an intercultural discourse approach was used. As recommended by Glaser \& Strauss (2009), the creators of this theory, it should be based on research, and be grounded in research. K. Konecki (2000) claims that theory emerges in the course of systematically conducted field studies, from empirical data that directly refer to the observed part of social reality (Jemielniak, 2012). During the empirical research, ten interviews were conducted with Polish scientists from the University of Warsaw, the Warsaw School of Economics, and the University of Adam Mickiewicz in Poznan all knowing business German (negotiations, business ethics) and intercultural communication (5 interviews). Additionally, interviews were conducted with Polish managers (German-speaking) from companies with German capital (5 interviews). Interviews (the voice) were recorded on a storage medium and then transcribed. The texts along with emotions' markers of the interlocutors were classified and coded in order to generate the theory. There is a number of variants responsible for the strategy of selecting a qualitative research sample. One of them is expressed in four aspects: people, activities, events and processes, where the researcher should pre-plan the sampling logic and be flexible when conducting research, when the changes relate to processes, events and participation (Creswell \& Poth, 2017, p. 158). According to the typology of the separation strategy for the sample presented by Creswell and Poth (2017), the research was carried out in accordance with the three assumptions of the so-called snowball (chain) effect - identifying events and matters from 'people who know other people who know something'. The so-called intensity of searching for information-rich centres which intensely manifest the phenomenon, but not in an extreme manner; so-called combined or mixed - encountering various 
interests and needs through triangulation and flexibility. A separate methodological assumption was the prospect of continuing the conducted research and extending it to groups of interlocutors from other scientific and business centres from Germany.

\section{Results}

Social changes, taking place after the war disaster, had their impact on the individual at all levels of stratification. The society severely burdened by war damage had to rise. It found it backbone in the work ethos. The social capital of Germany after the war did not degrade as it was in material structures: in factories, cities. The ever-flowing labour force from former Prussia and partly from East Germany supplemented these shortcomings. Most German entrepreneurs, great capitalists and financiers who were not directly connected with the fascist regime started to rebuild factories and capital (Wiesen, 2003). While the changes in social structures and the trend of the social market economy contributed to the creation of a new society liberated from the trauma of war, the great capital had to face new challenges. On the basis of many years, sometimes multi-generation entrepreneurship experiences, the German society had the established and deeply rooted institutions reflected in various forms of associations and cooperatives.

Stammtisch is an aged, mostly male institution of German political culture, which defines an intimate fraternal space where social knowledge and political courts are articulated, negotiated and questioned (Boyer, 2006, p. 327). Stammtisch is a table reserved for the same day by the same group of people in a neighbouring restaurant; is the basic unit of local social life (Koshar, 1987, pp. 2-24). In Stammitisch we find a communicative space saturated with informal dialectism, where the dialectical and often vulgar nature of intellectual practice allows for a multiplicity of epistemic modalities, ranging from sober and rational to drunken, poetic and idealistic (Boyer, 2005, p. 233). Stamtisch becomes a source of interpersonal relationships created within small communities and interest groups. The business can be rightly associated with a business activity, but in most cases it concerned craft structures, important from the point of view of the contemporary, industrialized German society. Cities were the main media for the exhibition of various meetings, mainly in public places, such as restaurants and pubs. At this point, the important role of Bildungsbürgertum should be mentioned - a social movement, a social class shaped in the 18th century, which stood out with its commitment to education and state affairs.

Germany is a nation talented in music. T. Mann (1993, p. 25-26) wrote that 'if Faust is to be a representative of the German soul, he should have a musical talent; because the German's relation to the world is abstract and mystical, i.e. musical'. After Balzac he went on to say that '(the Germans) gave the western world the most beautiful and socially unifying music'. Where does this extravert 
and open nature of music come from? One of the interlocutors in the research gives a quick answer: 'playing in some trios, quartets, around the households. Someone on the violin, someone on the cell, the piano (...) it was there, at the university, they could effortlessly complete two orchestras at the same time, among students'. An extraordinary opportunity to create and participate in various associations and organizations is a silent skill and capital that increases the efficiency of cooperation and the integration of resources.

Cooperative movement was a significant element in the social life of Germany, which was shaped throughout the 20th century. In the 19th century, Germany was one of the precursors of the idea of cooperative movement. Today, the majority of this type of organizations is centred around DGRV, that is the German Confederation of Cooperatives and Raiffeisen, which also has control functions over the entire cooperative network (Bohlke, 2008, p. 21). The history of the EWS company (Elektrizitatwerke Schonau) can be an example of the causative power that associations and cooperatives have. In a small local community, citizens concerned about the development of events related to the Chernobyl disaster in 1986 are undertaking activities to inform about the dangers associated with the production of nuclear energy and for this purpose they are establishing an association. After a few years, a cooperative is established, which buys shares in the local power grid, and after a dozen or so years, the company, supporting around 1000 small cogeneration power plants, generate revenues of about 24 million euros per year (Bohlke, 2008, p. 25). Other examples can be multiplied, including self-help initiatives (Mietshäuser Syndikat, 2019), from the health care and consulting (WeChange, 2019) and finance sectors. Therefore, it can be argued that the German tradition of creating associations is influenced by the centuries-long tradition of cooperation in achieving higher goals. If initially they were of an elevated character, almost ideological, they were a contribution to the shaping of needs, and then they were to be realized together. Until 1871, Germany was a group of nations (lands) that formed separate duchies and communities in business. Profit from integration, that is, the rise of Germany, which in a short time became a global economic and military power permanently established in the social consciousness as the only and right solution for future generations.

The idea of cooperative movement and the cooperatives themselves were among the key investors in the economy of the 1871-1913 periods. The first founders of these groups include Hermann Schultze-Delitzsch and Friedrich Wilhelm Raiffeisen, who wanted to oppose economically strong capital and commodity groups in a competitive market (Euczak, 2004). Some sources indicate that the beginning of cooperative movement in Europe is a cooperative established in the English city of Rochdale, in 1844 by the so-called Society of Equitable Pioneers (Bauman, 2000, p. 190). In addition, the economic development of the German state or some of its territories was cared for by all kinds of self-help associations represented through crafts, trade and small manufactures. The omnipresent tendency to cooperate and compete is constitutive for 
long-term historical and economic development. Its institutionally unwavering and stable character is significant, despite political turmoil, relating to the consolidation of cultural and civilizational parameters (Dobroczyński, 2002, p. 52). Each social group, without going beyond the scope of its existence, has its own catalogue of norms, values and beliefs. The interaction and cooperation of its members is conditioned by a uniform form of communication and a similar narrative. Participation in group activities is possible only if the same values and goals are shared. The element that forms the cohesion of the community is the resultant of all artefacts produced by members in the form of a social norm. An example of the EWS cooperative is a community of purpose, which defined further activities of the group.

The non-market transfer of knowledge that can be observed by penetrating the pedigree of entrepreneurial attitudes in German society, especially in the bourgeoisie and the petty bourgeoisie, could have helped to shape the seeds of a big capital. However, it seems that it would not be possible without traditional and customary family ties.

During the period of industrial changes in Germany in the 19th century, there are several components that contributed to the creation of entrepreneurship among the population living mainly in the city. At the institutional level, they included: the prospect of economic opportunities, lack of alternative development paths leading to the achievement of economic and social success, a gap in the state-legal barriers, respect for and tolerance of independent, profit-oriented commercial activities. This dominant institutional system was supported by striving, despite the obstacles, for success in running an enterprise for the good of the family or those in need of its members. The necessity to care for the loved ones was the justification of the efforts and determination in many bourgeois families - the most famous examples from that period were the figures of Alfred Krupp and Werner Siemens (Kocka, 1997, p. 126). It should be noted here that the overwhelming majority of large German companies (also small and medium enterprises established between 1850 and 1880) have at least 150 years of tradition and while maintaining their family nature were and still are flexible enough and are characterized by an extraordinary stability constituted by 'dependence on the path' (Plumpe, 2016).

There are many things that support the validity of the claim that the families, mainly craftsmen, issued numerous entrepreneurial units based on the breakthroughs and crises. It was the desire to keep the company for the future and its expansion for the benefit of the present and future family that guaranteed its success. The work ethic had its meaning in several dimensions: it was to serve the loved ones and praise the good name of the family, the entrepreneur could justify his efforts by the well-being of the future generations, he demanded at least a partial subordination of individual interests by postponing the benefits for later and giving up the spectacular short-term benefits. In entrepreneurs' families, the youngest were instilled with the cult of independent work and respect for competitors in the 'non-feudal' manner. On the other hand, among large 
bourgeois families who already owned property (the Schrammow or Schoeller families), the upbringing of future entrepreneurs was based on instilling passion for the paths of great achievements - bourgeois honour and faithfulness of proven forms of work (Kocka, 1997, p. 131). The descendants of the owners of small and large plants and manufactures supported institutionally by the extensive educational system gained comprehensive knowledge and adaptation to subsequent functions in the enterprise not only because of direct access to positions belonging to the father or a relative, but also among business partners of the family, often in the same industry (Kocka, 1997, p. 134). This way, the 'non-market' mechanism worked and still does, an informal institution giving a better starting position in relation to representatives of the same generation, who use access to enterprises or the means to set them by market criteria. 'But no longer being 14 years old, he basically exactly knew that he will have a brewery to take over (after his father)' - this institution is still alive and upto-date in the German society.

The above-described models of socialization: first degree - the youngest representatives of the families of entrepreneurs were subjected by their next of kin who create them in them attitudes consistent with the roles they had to play and the second degree - obtained during education, co-created standards and values necessary in the later business activity. The 'cultural equipment' of the entrepreneur is a set of attitudes and beliefs. Therefore, it is assumed that the indicators of cultural market understood as universal, but also secondary dependencies with types of personality of a man representing the given community will be decided on through cultural dimensions from empirical data in the area of intercultural communication, ethics and business negotiations, because the organizational culture is a lens of social culture (Morgan, 1997, p. 134). Using metaphor of the musical mixing console, the thesis is made that every community and culture - in the anthropological sense - is equipped with a set of attributes, attitudes, and values that distinguish it from the other one. With a strong indication that the discrepancies are of no quantitative the sum of the characteristics, but qualitative nature - every community has the same number of values, the difference is the location of the slide console the maximum, average, minimum, etc. For example, there is no culture that does not have, e.g., no monochrome parameter at all.

In the discourse, for example business intercultural communication, one can distinguish a rich metaculture interpretation that is socially placed through cultural practices. A small range of discursive centres is identified, which thoroughly talks about communication and its meaning. The main centres provide sources of meaning for the participants of the topics they touch and which are important to them. People involved in the communication process, presume and create meanings about communication itself, but also about who they are, about what they do, about how relationships are established, about their emotions and feelings. Each of these centres can be activated depending on the situation analysis and communication needs (Carbaugh, 2017, p. 66). 
Therefore, the limited reach of discourses can be identified by the fact that members of different cultures tend to create stereotypical images of their counterparts in other groups - ethnic, social, professional, etc. The way we perceive others, representatives of the other group is the result of the accepted norms and beliefs of own community, which is often distant from the observations of the third group, also in relation to us. Achievements in the field of intercultural communication may bring some simplifications, it should be noted that they are complementary to stereotypes that may legitimize and give sense to the attitudes, beliefs and values represented by others (Gurirdham, 2011). The results of research conducted in organizations and presented, for example, by Richard Gesteland, Geert Hofstede, Fons Trompenaars, Edward Hall, but also John Mole, Richard Lewis and Milton Bennett (Hurn \& Tomalin, 2013, p. 20) provide sufficient evidence about the characteristics of different societies.

From these premises it can be learnt that the German culture is monochronic. It is deeply rooted in history and in the historical development of the whole society and embodies all social aspects in such a way that organizational culture reflects these features in almost every industry (Samovar et. al., 2014). 'Many of these stereotypical features, which we attribute to Germans, are de facto related to this Prussian drill' - high punctuality, compliance with deadlines and performing one actions at a time is valued. In addition, Germans 'are oriented to the implementation of the plan (...) that they lack this flexibility, that as soon as the plan exists, the plan is implemented and achieved' and are perceived as a low context society. The German language is formal, as are people who try to be specific about precision and facts (Neuliep, 2006, pp. 1-42). For example, 'it means that, for instance, in contrast to, let's say, Asians, they just tell you the information, you know, they say it straight to your face. And the Asian will try to go around it'. In the request for the performance of a task, the German interlocutors modify the request in accordance with the context of validity and the probability of completing the task, simultaneously they create their selection strategy based on the dependence on the urgency of the task. It is part of the German tradition that people speak simultaneously and acceptable to interrupt someone's statements to express their own opinion on what the other person is about to say (Kiesling \& Paulston, 2008).

Germany is also a prototypical culture. 'I would rather call it a question of healthy questioning of certain things, on the one hand. And on the other hand, management, whether of time, of people, or of the information'. The German business strategy is slow and methodological, without sense of humour and very involved. Germany is a nation of individualists who prefer face-toface contacts (Chaney \& Martin, 2004). They are task-oriented, and the specification and level of expertise is important to the extent that it decides about the best results. Germans do not like to make mistakes because they expect to be experts in their area of specialization, and mistakes lead to uncertainty that Germans want to avoid (Samovar et. al., 2014). For German managers, facts and rational arguments are perceived as a means of persuasion. Management 
through expert knowledge seems to be the main way in which Germans understand management. They talk in such a way as if technical duties and responsibility in management were not separated from each other (Joynt \& Warner, 2002). In addition, 'Germans are goal-oriented, for a specific thing. And we (Poles) are more oriented towards people (...) they focus on things, surnames'. Competitiveness is perceived as a problem in finding appropriate, specialized staff that will perform specialized tasks. The strong role of experts and the expectations that management does not have only technical competences, but also knowledge about the organization is a feature of German companies (Schneider \& Barsoux, 2003).

\section{Conclusion}

Through the founding elements (informal norms, customs, traditions, values), culture, also economic, creates barriers to institutional changes, stimulating the persistence of ineffective practices that have a direct impact on maintaining high transaction costs resulting in a decline in economic results (Bostan et al., 2016, p. 55). This cannot be said about the German community. All along the presented manifestations and ideas of opportunity to create and participate in various organizations, cooperatives and associations as well as transfer of knowledge systems within family enterprises can construct German economic society through the institutional lenses.

The contemporary image of the German economy is the result of institutional (formal) changes carried out by L. Erhard just after the war and the result of a trodden trail through elements of economic culture. The whole policy of implementing the social market economy institution took place after the economic and monetary reform (without the consent of the Allies) on June 21, 1948 (Dahl, 2015, p. 76). The role of global changes in this period should also be indicated here - the 'cold war', lack of budget expenditures for the army (post-war arrangements) and the Korean War - Germans as a key supplier of raw materials and machines. The segments that create economic culture and the reviving capital were and are the foundation of informal institutions. These include the broadly understood cooperative movement, the creation of associations that are the result of the existence and the need to consolidate strong social and family ties. In addition, the intense work ethos and 'deep institutional memory' is the high octane fuel of the German economy engine. The limitations of the study include: lack of description of the Protestant culture, wider context of formal institutions (Moszyński, 2016, pp. 371-383) and a deeper description of the influence of apprentice system and large capital families on the existence of institutions and elements of social psychology regarding changes in social awareness after the war trauma. Moreover, there could be mentioned the role of the notions provided by general idea of the German Customs Union emerged in nineteenth century. Therefore, the wider context of considerations is the space for further research on economic culture, also with reference to the Polish institutions. 


\section{References}

Bauman, Z. (2000). Ponowoczesność jako źródto cierpień. Warszawa: Sic.

Bohlke, R. (2008). Warunki rozwoju ekonomii spotecznej w Niemczech. Warszawa: DnBNord.

Bostan, I., Clipa, F., \& Clipa, R.I. (2016). Informal institutions and economic performance. Knowledge Horizons: Economics, 8(2).

Boyer, D. (2005). Spirit and system: media, intellectuals, and the dialectic in modern German culture. Chicago-London: University of Chicago Press.

Boyer, D. (2006). Conspiracy, history, and therapy at a Berlin Stammtisch. American Ethnologist, 33(3). doi:10.1525/ae.2006.33.3.327.

Carbaugh, D. (2017). Terms for talk, take 2: theorizing communication through its cultural terms and practices. In D. Carabaigh (Ed.), The handbook of communication in cross-cultural perspective. New York: Routledge.

Chaney, L.H., \& Martin, J.S. (2004). Intercultural business communication. Upper Saddle River: Pearson Prentice Hall.

Creswell, J.W. \& Poth, C.N. (2017). Qualitative inquiry and research design: choosing among five approaches. Thousand Oaks: Sage.

Dahl, M. (2015). Niemiecki model społecznej gospodarki rynkowej jako wzór dla polskich przemian systemowych po 1989 roku. Warszawa: Elipsa.

Dobroczyński, M. (2002). Ekonomiczne mocarstwa Unii Europejskiej. Toruń: Adam Marszałek.

Federowicz, M. (2004). Różnorodność kapitalizmu. Instytucjonalizm i doświadczenie zmiany ustrojowej po komunizmie. Warszawa: IFiS PAN.

Glaser, B.G. \& Strauss, A.L. (2009). Odkrywanie teorii ugruntowanej. Strategie badania jakościowego. Kraków: Nomos.

Guirdham, M. (2011). Communicating across cultures at work. Basingstoke: Palgrave Macmillan. doi:10.1007/978-0-230-34471-6.

Hurn, B., \& Tomalin, B. (2013). Cross-cultural communication: theory and practice. London: Palgrave Macmillan.

Jemielniak, D., (2012). Badania jakościowe. Warszawa: PWN.

Joynt, P., \& Warner, M. (Eds.). (2002). Managing across cultures: issues and perspectives. London: Thomson Learning.

Kiesling, S.F., \& Paulston, C.B. (Eds.). (2008). Intercultural discourse and communication: the essential readings. Hoboken: Wiley.

Kochanowicz, J., \& Marody, M. (2007). Pojęcie „kultury ekonomicznej” w wyjaśnianiu polskich przemian. In J. Kochanowicz, S. Mandes, \& M. Marody (Eds.), Kulturowe aspekty transformacji ekonomicznej. Warszawa: IPS.

Kocka, J. (1997). O historii spotecznej Niemiec. Poznań: Wydawnictwo Poznanskie. Konecki, K.T. (2000). Studia z metodologii badan jakościowych. Warszawa: PWN. Koshar, R. (1987). From Stammtisch to party: Nazi joiners and the contradictions of grass roots fascism in Weimar Germany. The Journal of Modern History, 59(1). doi:10.1086/243158. 
Łuczak, C., (2004). Dzieje gospodarcze Niemiec 1871-1990. Druga Rzesza i Republika Weimarska. Poznań: UAM.

Mann, T. (1993). O Niemczech i Niemcach. In C. Karolak (Ed.), Niemcy o sobie. Poznań: Instytut Zachodni.

Mietshäuser Syndikat. (2019). Retrieved 16.04.2019 from https://www.syndikat.org.

Morgan, G. (1997). Obrazy organizacji. Warszawa: PWN.

Moszyński, M., (2016). Institutional conditioning of the German labour market in the face of the global economic crisis 2008-2009. Ekonomia i Prawo. Economics and Law, 15(3). doi:10.12775/eip.2016.025.

Neuliep, J.W. (2006). Intercultural communication: a contextual approach. Thousand Oaks: Sage.

Orłowski, W.M. (2015). Czy Polska dogoni Niemcy? Warszawa: PWN.

Ostrom, E. (2005). Understanding institutional diversity. Princeton: Princeton University Press.

Pawlak, M., \& Srokowski, Ł. (2014). Instytucje i organizacje. Przekraczanie paradygmatów w badaniach nad organizacjami. In M. Pawlak, \& . Srokowski (Eds.). Pomiędzy i wewnątrz. Instytucje, organizacje i ich dziatania. Warszawa: IPSiR UW.

Phelps, E. (2013). Mass flourishing: how grassroots innovation created jobs, challenge, and change. Princeton: Princeton University Press.

Plumpe, W. (2016). German economic and business history in the 19th and 20th centuries. London: Palgrave Macmillan.

Porter, M. (2003). Postawy, wartości i przekonania a makroekonomia dobrobytu. In L. Harrison, \& S. Huntington (Eds.), Kultura ma znaczenie. Poznań: Zysk i S-ka.

Samovar, L.A., Porter, R.E., McDaniel, E.R., \& Roy, C.S. (2014). Intercultural communication: a reader. Boston: Cengage Learning.

Schneider, S.C., \& Barsoux, J.L. (2003). Managing across cultures. Harlow: Prentice Hall.

Stankiewicz, W. (2012). Ekonomika instytucjonalna. Zarys wyktadu. Warszawa: WSBiA.

Veblen, T. (1971). Teoria klasy próżniaczej. Warszawa: PWN.

WeChange. (2019). Retrieved 16.04.2019 from https:/ / wechange.de.

Wiesen, S.J. (2003). West German industry and the challenge of the Nazi past, 1945-1955. Chapel Hill: University of North Carolina Press.

Williamson, C.R. (2009). Informal institutions rule: institutional arrangements and economic performance. Public Choice, 139(3-4). doi:10.1007/ sl1127-009-9399-X. 


\section{Acknowledgements}

Author contributions: author has given an approval to the final version of the article.

Funding: this research was fully funded by the authors.

Note: the results of this study were presented at Second Scientific Conference Institutions: theory and practice (June, 19-20 2018, Torun, Poland). 